\title{
PENGGUNAAN PAKAN BERBASIS BUNGKIL KOPRA PADA PEMBESARAN IKAN BANDENG DI TAMBAK
}

\author{
Usman, Kamaruddin, Asda Laining, dan Neltje Nobertine Palinggi \\ Balai Penelitian dan Pengembangan Budidaya Air Payau \\ Jl. Makmur Dg. Sitakka No. 129, Maros 90512, Sulawesi Selatan \\ E-mail: siganus007@yahoo.com
}

(Naskah diterima: 12 Juli 2013; Disetujui publikasi: 22 Oktober 2013)

\begin{abstract}
ABSTRAK
Bungkil kopra merupakan hasil samping dari pengolahan kopra untuk menghasilkan minyak, berpotensi digunakan sebagai komponen utama dalam pakan ikan, khususnya ikan-ikan herbivora- omnivora, karena kandungan proteinnya cukup tinggi, ketersediaannya relatif banyak di daerah- daerah tertentu dengan harga murah. Penelitian ini bertujuan meningkatkan pemanfaatan bahan baku lokal (bungkil kopra) dalam pakan untuk pembesaran ikan bandeng di tambak. Penelitian dilakukan dengan menggunakan tambak berukuran $2.500 \mathrm{~m}^{2}$ sebanyak tiga unit, masing- masing disekat dengan waring menjadi dua bagian, sehingga menjadi enam petak (@ $1.250 \mathrm{~m}^{2}$ ). Ikan uji yang digunakan adalah yuwana ikan bandeng berukuran awal $67 \mathrm{~g} /$ ekor yang ditebar dengan kepadatan 6.000 ekor/ha. Tiga pakan uji yang terdiri atas dua pakan buatan berbahan utama tepung bungkil kopra yaitu 65\% (BK-65) dan 55\% (BK-55), serta pakan komersil (PK). Hasil penelitian menunjukkan bahwa ikan yang diberi pakan berbasis bungkil kopra (BK-65 dan BK-55) cenderung memiliki koefisien kecernaan bahan kering, protein, dan energi yang lebih rendah dari pada pakan komersil. Namun laju pertumbuhan harian ikan, rasio konversi pakan, dan rasio efisiensi protein tidak berbeda nyata $(P>0,05)$ di antara perlakuan, kecuali bobot akhir ikan tertinggi $(P<0,05)$ pada ikan yang diberi pakan komersil. Sementara retensi lemak tertinggi terjadi pada ikan yang diberi pakan PK, diikuti berturut- turut yang diberi pakan BK-65 dan BK-55. Pakan berbasis bungkil kopra layak digunakan sebagai pakan alternatif dalam pembesaran ikan bandeng tradisional (+) di tambak.
\end{abstract}

KATA KUNCl: bungkil kopra, pakan, ikan bandeng, pertumbuhan, tambak

ABSTRACT: Utilization of copra cake base diet for milkfish grow- out in pond. By: Usman, Kamaruddin, Asda Laining, and Neltje Nobertine Palinggi

Copra cake is a by-product in copra processing to produce coconut oil. It has potential to be used as a major component of feed ingredient for herbivorous-omnivorous fish, because it has relatif high of protein content, abundance in some area and low-price. The objective of the experiment was to increase the utilization of local raw-material (copra cake) in diet for milkfish grow-out. Three 2,500 $\mathrm{m}^{2}$ ponds, and the every pond was divided into two equal compartments by monoethilen-net, so become six pond units (@ 1,250 $\mathrm{m}^{2}$ ). Juvenile of milkfish $\left(67 \mathrm{~g}\right.$ ) were stocked into the each 1,250 $\mathrm{m}^{2}$ pond with density of $6,000 \mathrm{fish} / \mathrm{ha}$. Three test diets with consist of two dry pellets contain $65 \%$ of copra cake (BK-65) or $55 \%$ of copra cake (BK-55), and commercial feed. The results shown that the BK-65 and BK-55 tend to have dry matter, protein, and energy digestibility coefficients were lower compared to the commercial feed. However, 
the specific growth rate, feed conversion ratio, and protein efficiency ratio didn't differ significantly $(P>0.05)$ among treatments. Except, the final weight of fish was signicficantly $(<0.05)$ higher value for fish fed commercial feed compared to the others feed tests. The higherst lipid retention was found in fish fed commercial feed, was followed by fish fed BK-55 and BK-65 respectively. The copra cake based feeds were suitable as alternative feed for milkfish grow-out in traditional ( + ) pond system.

KEYWORDS: copra cake, feed, milkfish, growth, pond

\section{PENDAHULUAN}

Pakan merupakan salah satu faktor kunci dalam kegiatan budidaya perikanan dan kontribusinya dapat mencapai $70 \%$ dari total biaya produksi pada kegiatan budidaya intensif (Harris, 2006). Meningkatnya kepadatan ikan tentu membutuhkan juga peningkatan jumlah kebutuhan pakan seiring dengan peningkatan biomassa ikan, sementara daya dukung pakan alami dari areal budidaya tersebut sangat terbatas. Akibat daya dukung dari pakan alami yang tidak mencukupi dan agar ikan tetap dapat tumbuh normal, maka diperlukan adanya tambahan pakan dari luar.

Saat ini, harga pakan komersil cenderung semakin meningkat, sementara harga ikan hasil budidaya tidak mengalami peningkatan yang seimbang, menyebabkan pembudidaya ikan terus mencari pakan alternatif yang dapat menunjang keberlanjutan usahanya. Para pembudidaya ikan bandeng di tambak misalnya, saat ini banyak menggunakan mi apkiran sebagai pakan alternatif. Namun, akibat permintaan yang banyak menyebabkan mi apkiran ini juga menjadi rebutan para pembudidaya dan menjadi langka. Oleh karena itu, harus diupayakan pakan alternatif lainnya, utamanya dengan menggunakan bahan baku lokal yang ketersediaannya cukup banyak dan sepanjang tahun.

Tepung bungkil kopra merupakan salah satu limbah (hasil samping) dari pengolahan kopra untuk menghasilkan minyak kelapa. Tepung bungkil kopra ini berpotensi untuk digunakan sebagai komponen utama dalam pakan ikan, khususnya ikan-ikan herbivoraomnivora, karena kandungan proteinnya relatif tinggi sekitar $18 \% 24 \%$ meskipun juga memiliki kandungan serat kasar yang cukup tinggi sekitar 13\% 16\%(Hertampf \& Piedad- Pascual, 2000). Pengamatan di lapangan juga menunjukkan bahwa ikan bandeng yang dipelihara di tambak dengan kepadatan cukup tinggi sekitar 25.000 ekor/ ha dapat mengonsumsi dan memanfaatkan langsung tepung bungkil kelapa ini dengan baik seperti pakan bandeng (pelet) komersil (Makmur, komunikasi pribadi, 2010). Beberapa pembudidaya juga menginformasikan bahwa ikan bandeng yang diberi makanan bungkil kelapa atau bungkil kopra dapat bebas dari bau lumpur (geosmine). Sementara produksi bungkil kopra di beberapa tempat seperti Sulawesi Selatan cukup tinggi dengan harga sekitar Rp 2.000-2.500/ kg atau lebih rendah dari harga dedak halus yaitu sekitar Rp 2.500-3.000/ kg yang merupakan salah satu bahan dasar utama dalam pakan ikan bandeng. Berdasarkan hal tersebut, maka untuk mendapatkan harga pakan ikan bandeng yang murah dan ekonomis khususnya pada pemeliharaan di tambak, maka pemanfaatan tepung bungkil kopra dalam pakan ikan ini perlu dioptimalkan.

Ikan bandeng merupakan salah satu komoditas yang banyak dikembangkan oleh pembudidaya ikan di Indonesia termasuk kawasan Asia Tenggara lainnya. Ikan ini cenderung tergolong herbivora- omnivora (Huisman, 1987; Bagarinao, 1994), dan pada ukuran yuwana membutuhkan protein pakan yang relatif rendah untuk tumbuh secara optimum yaitu sekitar 24\% (Sumagaysay \& Borlongan, 1995), 23\% 29\%(Sudradjat, 2010), bahkan pakan ikan bandeng komersil yang beredar di pasaran ada yang memiliki kadar protein sekitar 17\% Meskipun Pascual (1989 dalam Millamena 2002) melaporkan bahwa kadar protein dalam pakan untuk pertumbuhan optimum yuwana ikan bandeng antara 30\% $40 \%$ Perbedaan kebutuhan kadar protein dalam pakan untuk ikan bandeng ini dipengaruhi oleh banyak faktor utamanya sumber protein pakan, susunan bahan dalam formulasi pakan dan metode pemeliharaan ikan.

Sehubungan dengan hal tersebut, maka telah dilakukan penelitian dengan tujuan untuk meningkatkan pemanfaatan bahan baku lokal (bungkil kopra) dalam pakan untuk pembesaran ikan bandeng di tambak. 


\section{BAHAN DAN METODE}

\section{Pakan Uji}

Ada tiga pakan uji yang dicobakan dalam penelitian ini yang terdiri atas dua pakan buatan berbasis bungkil kopra yaitu mengandung 65\%bungkil kopra (BK-65) dan mengandung 55\%bungkil kopra (BK-55), serta pakan komersil (PK) (Tabel 1). Jumlah pemberian protein harian ke dalam tambak disamakan $(6 \mathrm{~g} /$ kg ikan) (Sumagaysay, 1991), sehingga dosis pemberian pakan hariannya sebanyak 2,7\% dari biomassa ikan uji. Aplikasi pakan uji ini didesain dengan rancangan acak lengkap yang terdiri atas tiga perlakuan dan dua ulangan.

\section{Tambak Percobaan dan Pemeliharaan} Ikan

Penelitian ini dilakukan di tambak Instalasi Penelitian Marana, Balai Penelitian dan Pengembangan Budidaya Air Payau. Wadah percobaan yang digunakan adalah tiga petak tambak berukuran $2.500 \mathrm{~m}^{2}$, masing- masing dibagi dua (disekat dengan waring, sehingga menjadi enam petak dengan ukuran luas masing- masing $1.250 \mathrm{~m}^{2}$ ). Tambak terlebih dahulu dilakukan persiapan berupa pemberantasan hama, pengeringan, pengapuran (dolomit $600 \mathrm{~kg} / \mathrm{ha}$ ), dan pemupukan (urea 150 $\mathrm{kg} / \mathrm{ha}$ dan TSP $75 \mathrm{~kg} / \mathrm{ha}$ ). Setelah makanan alami tumbuh, maka dilakukan penebaran yuwana ikan bandeng dengan bobot rata- rata

Tabel 1. Komposisi bahan dan analisis proksimat pakan uji (\%bobot kering)

Table 1. Composition and proximate analysis of the experimental diets (\% dry matter)

\begin{tabular}{|c|c|c|c|}
\hline \multirow{2}{*}{$\begin{array}{c}\text { Bahan } \\
\text { Ingredients }\end{array}$} & \multicolumn{3}{|c|}{ Pakan uji (Test diets) } \\
\hline & $\begin{array}{l}\text { Bungkil kopra } 65 \\
\text { Copra cake } 65\end{array}$ & $\begin{array}{l}\text { Bungkil kopra } 55 \\
\text { Copra cake } 55\end{array}$ & $\begin{array}{l}\text { Pakan komersil } \\
\text { Commercial feed }\end{array}$ \\
\hline Tepung ikan lokal (Local fish meal) & 10.00 & 15.00 & \\
\hline $\begin{array}{l}\text { Tepung bungkil kopra } \\
\text { Copra cake meal }\end{array}$ & 65.00 & 55.00 & \\
\hline Dedak halus (Rice brand) & 10.00 & 10.00 & \\
\hline Tapioka (Cassava starch ) & 14.50 & 19.50 & \\
\hline Vitamin mix ${ }^{1)}$ & 0.25 & 0.25 & \\
\hline Mineral mix ${ }^{2)}$ & 0.25 & 0.25 & \\
\hline Total & 100.00 & 100.00 & 100.00 \\
\hline \multicolumn{4}{|c|}{ Analisis proksimat (Proximate analysis) } \\
\hline - Protein kasar (Crude protein) & 20.3 & 21 & 21.5 \\
\hline - Lemak (Lipid) & 14.9 & 13.3 & 6.6 \\
\hline - BETN (NFE) ${ }^{3)}$ & 43.5 & 44.8 & 56.3 \\
\hline - Serat kasar (Crude fibre) & 10.8 & 9.7 & 7.7 \\
\hline - Abu (Ash) & 10.5 & 11.2 & 7.9 \\
\hline - Energi total (Total energy ) (MJ/ kg) & 18.2 & 17.9 & 17.4 \\
\hline Harga pakan (Feed price) (Rp/ kg) & 3,500 & 4,000 & 6,100 \\
\hline
\end{tabular}

Keterangan (Remark):

1) Vitamin mix (dalam 1 kg pakan): Vit. A 3000 IU; Vit. D 500 IU; Vit. E 2 IU; Vit. K 0,5 mg; Vit. B 0,5 mg; Vit. $\mathrm{B}_{2}$ 1,25 mg; Vit. $\mathrm{B}_{6}$ 0,125 mg; Vit. $\mathrm{B}_{12} 3 \mathrm{mg}$; Vit. C 6,25 mg; Calcium D- Pentathenate 1,5 mg; Niacin 10 mg, dan Cholin chloride $2,5 \mathrm{mg}$

2) Mineral mix (dalam 1 kg pakan): Mananese 30 mg; Iron 5 mg; lodine 0,05 mg; Zinc 25 mg; Cobalt 0,05 mg; dan Copper $1 \mathrm{mg}$

3) BETN (Bahan ekstrak tanpa nitrogen) / NFE (Nitrogen free extract)

4) Energi total dihitung berdasarkan nilai konversi protein = 23,6 MJ/kg; lemak 39,5 MJ/kg; dan BETN = 17,2 $\mathrm{MJ} / \mathrm{kg}$ (NRC, 1993) (Calculation from the determined protein, lipid and NFE of the diet using gross energy convertion coefficients of 23,6; 39,5 and 17,2 MJ/kg respectively (National Research Council, 1993)) 
$67 \pm 6,5$ g; sebanyak masing- masing 750 ekor/ $1.250 \mathrm{~m}^{2}$ atau 6.000 ekor/ha. Setelah satu bulan pemeliharaan ikan tersebut, makanan alami mulai berkurang secara drastis, sehingga mulai dilakukan pemberian pakan buatan (perlakuan). Sebelum pemberian pakan buatan, terlebih dahulu dilakukan sampling sehingga didapatkan data bobot rata- rata ikan $90 \pm 10,1 \mathrm{~g}$ sebagai acuan penentuan awal dosis pemberian pakan.

Selama pemeliharaan, dilakukan pergantian air setiap dua minggu sebanyak 30\% Untuk mempertahankan produksi makanan alami dan menyuplai nutrien untuk mempercepat proses dekomposisi bahan organik, maka dilakukan pemberian pupuk Phonska (mengandung nitrogen- phospor-kalium-sulphur dengan perbandingan 15-15-15-10) sebanyak 24 kg/ ha setiap setelah pergantian air. Monitoring kualitas air yang meliputi: suhu, $\mathrm{pH}$, salinitas, dan oksigen terlarut dilakukan setiap minggu secara in situ dan di laboratorium, sementara TAN (total amonia nitrogen), nitrit, nitrat, dan fosfat dilakukan setiap dua minggu. Pengamatan produktivitas primer dan plankton dilakukan pada awal dan akhir bulan pertama pemberian pakan buatan dan selanjutnya setiap dua minggu, sementara pengamatan total bakteri heterotrof dilakukan setiap bulan. Produktivitas primer diukur menggunakan botol terang (BT)- botol gelap (BG) berdasarkan metode yang dilakukan oleh Tambaru \& Samawi (2008). Sementara kelimpahan dan komposisi jenis plankton diamati menggunakan mikroskop dan alat bantu Sedgewick Rafter Counting Cell (SRC) serta buku identifikasi plankton dari Yamaji (1979) dan Newell \&Newell (1977).

Selain itu, juga dilakukan analisis kecernaan pakan. Wadah percobaan yang digunakan berupa tiga tanki conical fibre glass bervolume 200 L yang dilengkapi dengan sistem aerasi dan pergantian air. Ikan bandeng ukuran sekitar 150-200 g ditebar dengan kepadatan 10 ekor/tank. Ketiga pakan uji tersebut ditambahkan kromium oksida $\left(\mathrm{Cr}_{2} \mathrm{O}_{3}\right)$ sebagai indikator masing- masing sebanyak 0,70\% (Furuichi, 1988). Ikan diberi pakan uji secara satiasi per hari dengan frekuensi dua kali sehari pada pagi dan sore hari. Beberapa saat setelah pemberian pakan, air dikeluarkan untuk membuang sisa pakan yang ada dengan membuka kran bagian bawah. Sebelum pengambilan feses, ikan diadaptasikan dengan pakan uji tersebut selama satu minggu, lalu pengumpulan feses dilakukan setiap tiga jam untuk mencegah terjadi leaching nutrien pada feses. Feses yang terkumpul secepatnya disimpan dalam freezer hingga cukup untuk analisis kemudian dikeringkan.

\section{Perhitungan Respons Pertumbuhan} Ikan dan Pemanfaatan Pakan Uji

Setelah aplikasi pakan uji selama 120 hari, peubah pertumbuhan yang dihitung adalah laju pertumbuhan spesifik (SGR) ikan berdasarkan formulasi berikut (Schulz et al., 2005).

$$
\operatorname{SGR}\left(\% \text { day }^{-1}\right)=\frac{\ln \text { We }-\ln \text { Ws }}{d} \times 100 \%
$$

di mana:

We $=$ bobot rata- rata individu ikan pada akhir percobaan $(\mathrm{g})$, Ws = bobot rata- rata individu ikan pada awal percobaan $(\mathrm{g})$, dan $\mathrm{d}=$ periode pemeliharaan (hari)

Rasio konversi pakan $(\mathrm{FCR})=$ Jumlah pakan yang diberikan (g)/ (Pertambahan bobotikan + Bobot ikan mati (g))

Rasio efisiensi protein $=$ Pertambahan bobot ikan (g bobot basah)/ Jumlah konsumsi protein (g bobot kering) (Takeuchi, 1988; Hardy, 1989)

Retensi protein $(\%=100 \times$ Pertambahan protein ikan (g) / Jumlah konsumsi protein (g)\} (Takeuchi, 1988)

Sintasan $(\%)=\{$ umlah ikan akhir / Jumlah ikan awal\} $\times 100$

Koefisien kecernaan (AD) bahan kering (DM) atau biasa disebut kecernaan total pakan dihitung berdasarkan rumus (Mohapatra et al., 2012) berikut:

$$
A D_{D M}(\%)=\left[1-\left[\frac{M_{D}}{M_{F}}\right]\right] \times 100 \%
$$

di mana:

$M_{D}$ dan $M_{F}$ berturut- turut adalah konsentrasi indikator $\mathrm{Cr}_{2} \mathrm{O}_{3}$ dalam pakan dan feses

Sementara koefisien kecernaan nutrien (NUT) pakan yang meliputi protein kasar (CP), lemak (L), dan energi (E) dihitung berdasarkan rumus (Watanabe, 1988; Hardy, 1989; Masagounder et al., 2009) berikut:

$$
A D_{N U T}(\%)=\left[1-\left[\frac{M_{D} \times A_{F}}{M_{F} \times A_{D}}\right]\right] \times 100 \%
$$


di mana:

$A_{D}$ and $A_{F}$ adalah konsentrasi protein kasar, lemak, dan energi berturut- turut dalam pakan dan feses.

\section{Analisis Kimia dan Statistik}

Pada analisis proksimat pakan dan feses, sampel yang representative dianalisis berdasarkan metode AOAC International (1999): bahan kering (DM) dikeringkan dengan oven pada suhu $105^{\circ} \mathrm{C}$ selama 16 jam, serat kasar dengan ekstraksi ether, abu dengan pembakaran dalam muffle furnace pada suhu $550^{\circ} \mathrm{C}$ selama 24 jam, protein kasar dianalisis dengan micro-Kjeldahl, lemak dideterminasi secara gravimetric dengan extraksi chloroform: methanol pada sampel. Kadar kromium dalam sampel pakan dan feses dianalisis berdasarkan prosedur Takeuchi (1988).

Peubah yang diamati berupa laju pertumbuhan spesifik ikan, rasio konversi pakan, rasio efisiensi protein, retensi protein, retensi lemak, komposisi kimia tubuh, kecernaan nutrien pakan, analisis biaya produksi, dan kualitas air (Total ammonia nitrogen (TAN), nitrit, nitrat, fosfat, $\mathrm{pH}$, alkalinitas, oksigen terlarut, salinitas, dan produktivitas primer, bakteri heterotrof). Beberapa hasil pengamatan peubah tersebut dianalisis ragam dan dilanjutkan dengan uji nilai tengah dengan LSD taraf 5\%(Steel \& Torrie, 1995), dan sebagian dianalisis secara deskriptif.

\section{HASIL DAN BAHASAN}

Salah satu upaya untuk meningkatkan produksi dan menekan biaya pada kegiatan budidaya ikan adalah memanfaatkan bahan baku lokal pakan yang tersedia secara memadai khususnya limbah (sisa hasil pengolahan) pertanian/perkebunan seperti bungkil kopra. Pemanfaatan bungkil kopra sebagai bahan baku utama dalam pakan telah dicobakan pada budidaya pembesaran ikan bandeng di tambak.

\section{Kecernaan Pakan}

Kecernaan pakan merupakan salah satu indikator awal untuk mengukur kemampuan ikan memanfaatkan pakan. Nilai koefisien kecernaan pakan uji disajikan pada Tabel 2 . Pada tabel tersebut terlihat bahwa kedua pakan yang berbasis bungkil kopra cenderung memiliki koefisien kecernaan bahan kering, protein, dan energi yang lebih rendah daripada pakan komersil. Salah satu kemungkinan penyebab rendahnya kecernaan bahan kering, protein, dan energi pakan berbasis bungkil kopra ini adalah kandungan serat kasar pakan yang cukup tinggi $(9,7 \% 10,8 \%$ ) (Tabel 1). Kandungan serat kasar pakan yang tinggi merupakan kontribusi dari komponen bahan utama bungkil kopra yang mengandung serat kasar cukup tinggi $(13,5 \%$. Menurut NyinaWamwiza et al. (2010), kandungan serat kasar bahan yang tinggi dalam pakan dapat menyebabkan kecernaan bahan kering dan energi pakan menjadi rendah. Selain serat kasar, bungkil kopra juga mengandung non-starch polysaccarida yang cukup tinggi khususnya manna dan galactomannan (25\% 30\%), yang diketahui memiliki sifat anti-nutrisi pada beberapa jenis hewan monogastic (Sundu et al., 2009). Koefisien kecernaan lemak pada pakan berbasis bungkil koprajuga cenderung lebih rendah dibandingkan pakan komersil (Tabel 2). Menurut De Silva \& Perera (1984), kecernaan nutrien bahan atau pakan cenderung menurun jika kandungan nutrien dalam bahan/pakan tersebut sangat tinggi. Kandungan lemak pakan masing- masing untuk pakan berbasis kopra 65\%sebanyak14,9\% dan yang berbasis bungkil kopra $55 \%$ sebanyak $13,3 \%$ sedangkan pakan komersil hanya 6,6\%

Tabel 2. Koefisien kecernaan pakan uji pada ikan bandeng

Table2. Apparent digestibility coefficients of test diest for milkfish

\begin{tabular}{ccccc}
\hline \multirow{2}{*}{$\begin{array}{c}\text { Pakan uji } \\
\text { Test diets }\end{array}$} & \multicolumn{3}{c}{$\begin{array}{c}\text { Peubah kecernaan pakan } \\
\text { Variable of feed digestibility (\%) }\end{array}$} \\
\cline { 2 - 6 } & $\begin{array}{c}\text { Bahan kering } \\
\text { Dry matter }\end{array}$ & Protein & $\begin{array}{c}\text { Lemak } \\
\text { Lipid }\end{array}$ & $\begin{array}{c}\text { Energi } \\
\text { Energy }\end{array}$ \\
\hline Bungkil kopra 65 (Copra cake 65) & 68.0 & 87.5 & 91.2 & 83.0 \\
Bungkil kopra 55 (Copra cake 55) & 67.5 & 87.0 & 92.1 & 82.1 \\
Pakan komersil (Commercial feed) & 73.9 & 91.6 & 93.1 & 87.4 \\
\hline
\end{tabular}


(Tabel 1). Kecernaan nutrien untuk kedua pakan berbasis bungkil kopra tersebut relatif sama, meskipun salah satu dari pakan tersebut memiliki kandungan bungkil kopra lebih banyak $(65 \%)$ dengan kandungan tepung ikan lebih sedikit (10\%) daripada yang lainnya (mengandung bungkil kopra 55\%dengan tepung ikan $15 \%$. Hal ini kemungkinan kandungan tepung tapioka lokal yang cukup tinggi (19,5\% dalam pakan berbasis bungkil kopra $55 \%$ sehingga memberikan pengaruh negatif terhadap kecernaan nutrien pakan tersebut. Tepung tapioka lokal grade-2 yang digunakan sebagai binder dan sumber energi (karbohidrat) tambahan dalam pakan ini merupakan salah satu produk dari pengolahan ubi kayu tanpa membuang kulit luar dan kulit dalamnya.

\section{Performansi Pertumbuhan Ikan dan Pemanfaatan Pakan Uji}

Setelah pemeliharaan dan pemberian pakan uji selama 120 hari, ikan bandeng yang diberi pakan berbahan utama bungkil kopra $65 \%$ maupun yang berbahan utama bungkil kopra $55 \%$ memiliki laju pertumbuhan dan rasio kon- versi pakan yang relatif sama $(P>0,05)$ dengan ikan yang diberi pakan komersil (Tabel 3). Hal ini menunjukkan bahwa bungkil kopra tersebut dapat dimanfaatkan oleh ikan bandeng untuk pertumbuhannya. Namun demikian, bobot akhir ikan yang diberi pakan berbasis bungkil kopra ini lebih rendah $(P<0,05)$ dibandingkan ikan yang diberi pakan komersil.

Salah satu faktor nutrisi yang menentukan pertumbuhan ikan adalah kandungan protein dan profil asam amino pakan. Kandungan protein pakan yang dicobakan dalam penelitian ini rata- rata $20 \% 21 \%$ Hasil analisis ragam menunjukkan bahwa nilai rasio efisiensi protein pakan tidak menunjukkan adanya perbedaan yang nyata $(P>0,05)$ di antara perlakuan (Tabel 3). Bila melihat tingkat kecernaan bahan kering, protein dan energi pakan yang relatif rendah pada pakan berbasis bungkil kopra tersebut, dan adanya laju pertumbuhan ikan, rasio konversi pakan, dan rasio efisiensi protein pakan yang tidak berbeda nyata di antara perlakuan, maka hal ini diduga karena adanya peran makanan alami yang tumbuh di tambak. Makanan alami masih cukup berperan dalam budidaya ikan bandeng di tambak (skala tra-

Tabel 3. Performansi pemanfaatan pakan uji dan pertumbuhan ikan bandeng di tambak

Table3. Feed utilization and growth performances of milkfish in the ponds

\begin{tabular}{|c|c|c|c|}
\hline \multirow[b]{2}{*}{ Peubah (Variable) } & \multicolumn{3}{|c|}{ Pakan uji (Test diets) } \\
\hline & $\begin{array}{l}\text { Bungkil kopra } 65 \\
\text { Copra cake } 65\end{array}$ & $\begin{array}{l}\text { Bungkil kopra } 55 \\
\text { Copra cake } 55\end{array}$ & $\begin{array}{l}\text { Pakan komersil } \\
\text { Commercial feed }\end{array}$ \\
\hline Bobot akhir (Final weight) (g) & $312 \pm 4.2^{\mathrm{a}}$ & $309 \pm 7.1^{\mathrm{a}}$ & $330 \pm 4.2^{b}$ \\
\hline $\begin{array}{l}\text { Laju pertumbuhan spesifik (\% hari) } \\
\text { Specific gronth rate (\%days) }\end{array}$ & $1.04 \pm 0.01^{\mathrm{a}}$ & $1.04 \pm 0.01^{a}$ & $1.06 \pm 0.02^{\mathrm{a}}$ \\
\hline Rasio konversi pakan (Feed conversion ratio) *) & $2.47 \pm 0.03^{a}$ & $2.48 \pm 0.11^{\mathrm{a}}$ & $2.39 \pm 0.10^{\mathrm{a}}$ \\
\hline Rasio efisiensi protein (Protein efficiency ratio) & $2.20 \pm 0.03^{a}$ & $2.12 \pm 0.09^{a}$ & $2.25 \pm 0.09^{a}$ \\
\hline Sintasan (Survival rate) $(\%$ & $97.9 \pm 1.7^{a}$ & $98.5 \pm 1.4^{a}$ & $95.3 \pm 0.6^{a}$ \\
\hline Produksi (kg/ petak) (Production (kg/pond)) & $229 \pm 1.0^{\mathrm{a}}$ & $228 \pm 8.5^{a}$ & $236 \pm 4.7^{a}$ \\
\hline Retensi protein ( Protein retention ) (\% $/$ & $38.2 \pm 0.6^{\mathrm{a}}$ & $37.7 \pm 0.3^{\mathrm{a}}$ & $38.5 \pm 0.6^{a}$ \\
\hline Retensi lemak (Lipid retention) ) (\%) & $14.7 \pm 0.4^{\mathrm{a}}$ & $17.7 \pm 2.8^{\mathrm{a}}$ & $62.4 \pm 10.4^{b}$ \\
\hline $\begin{array}{l}\text { Biaya pakan (Rp)/ kg produksi ikan } \\
\text { Feed cost (Rp)/kg of fish production }\end{array}$ & 8,650 & 9,950 & 14,600 \\
\hline $\begin{array}{l}\text { Harga penjualan ikan-biaya pakan (Rp)/ petak } \\
\text { Fish production pricefeed cost (Rp)/compartment }\end{array}$ & $1,896,000$ & $1,715,250$ & $1,495,250$ \\
\hline
\end{tabular}

Keterangan (Remark):

Nilai dalam baris yang sama diikuti oleh superscript yang sama menunjukkan tidak berbeda nyata $(P>0,05)$ (Means in the same row followed by the same superscript are not significantly different $(P>0.05)$ ) 
disonal plus- semi intensif), khususnya untuk mensuplai kebutuhan nutrien essensial yang tidak tersedia secara memadai di dalam pakan tambahan (Sumagaysay, 1991; Sumagaysay \& Borlongan, 1995; Yap \& Villaluz, 2010).

Ikan bandeng yang diberi pakan berbasis bungkil kopra dan pakan komersil memiliki nilai retensi protein $(37,7 \% 38,5 \%$ yang relatif sama $(P>0,05)$. Sementara ikan yang diberi pakan komersil memiliki retensi lemak yang tertinggi $(62,4 \%)$, diikuti ikan yang diberi pakan berbasis bungkil kopra $55 \%(17,7 \%$, dan terendah pada ikan yang diberi pakan berbasis bungkil kopra $65 \%(14,7 \%$ (Tabel 3). Tingginya retensi lemak pada ikan yang diberi pakan komersil menunjukkan bahwa pada ikan tersebut terjadi proses lipogenesis yang tinggi. Kandungan lemak pakan yang relatif rendah $(6,6 \%$ bobot kering) mampu membuat kandungan lemak tubuh ikan cukup tinggi $(7,1 \%$ bobot basah atau 22,8\%bobot kering) (Tabel 4). Hal ini terjadi karena kecernaan energi pakan yang cukup tinggi $(87,4 \%$ ) (Tabel 2). Sementara pada ikan yang diberi pakan berbasis bungkil kopra, retensi lemaknya hanya $14,7 \% 17,7 \%$ dan keduanya tidak berbeda nyata $(P>0,05)$. Retensi lemak yang rendah ini disebabkan karena selain kadar lemak pakan yang cukup tinggi (13,3\% 14,9\%), kandungan lemak tubuh juga relatif rendah $(4,2 \% 4,5 \%$ bobot basah atau $15,0 \% 15,4 \%$ bobot kering) akibat kecernaan energi yang relatif rendah dibandingkan jenis pakan komersil, sehingga laju lipogenesis relatif rendah dibandingkan pada ikan yang diberi pakan komersil tersebut.

Ikan yang diberi pakan berbasis bungkil kopra $65 \%$ cenderung memiliki biaya pakan/ $\mathrm{kg}$ produksi ikan yang terendah, kemudian disusul ikan yang diberi pakan berbasis bungkil kopra $55 \%$ dan tertinggi yang diberi pakan komersil (Tabel 3). Sementara selisih antara harga penjualan ikan dengan biaya pakan, tertinggi diperoleh pada ikan yang diberi pakan berbasis bungkil ko pra $65 \%$ kemudian disusul ikan yang diberi pakan berbasis bungkil kopra 55\% dan terendah yang diberi pakan komersil. Ikan yang diberi pakan komersil memiliki harga jual ikan rata- rata lebih tinggi dibandingkan pada ikan yang beri pakan berbasis bungkil kopra, karena ikan tersebut dijual per ekor (per individu) dan ikan yang diberi pakan komersil tampak memiliki ukuran yang relatif lebih besar (memiliki kadar lemak tubuh yang lebih tinggi).

\section{Kualitas Air}

Sebagai hewan akuatik, ikan membutuhkan kualitas air media pemeliharaan yang optimal untuk tumbuh secara maksimum. Kisaran media kualitas air selama pemeliharaan disajikan pada Tabel 5. Pada tabel tersebut terlihat bahwa beberapa peubah kualitas air seperti suhu, $\mathrm{pH}$, amonia total (TAN), nitrit, nitrat, dan fosfat relatif cukup baik bagi pertumbuhan ikan bandeng. Sementara kandungan oksigen ter-

Tabel 4. Komposisi proksimat tubuh ikan bandeng sebelum dan setelah pemberian pakan uji di tambak (\%bobot basah)

Table4. Whole body proximate composition of milkfish before and after fed the test diets in the pond (\% wet basis)

\begin{tabular}{|c|c|c|c|c|}
\hline \multirow{2}{*}{$\begin{array}{c}\text { Nutrien } \\
\text { Nutrients }\end{array}$} & \multirow{2}{*}{$\begin{array}{c}\text { Ikan } \\
\text { awal } \\
\text { Initial } \\
\text { fish }\end{array}$} & \multicolumn{3}{|c|}{ Setelah pemberian pakan uji (After fed the test diets) } \\
\hline & & $\begin{array}{c}\text { Bungkil kopra } 65 \\
\text { Copra cake } 65\end{array}$ & $\begin{array}{c}\text { Bungkil kopra } 55 \\
\text { Copra cake } 55\end{array}$ & $\begin{array}{l}\text { Pakan komersil } \\
\text { Commercial feed }\end{array}$ \\
\hline Protein kasar (Crude protein ) & 18.3 & $17.7 \pm 0.2^{\mathrm{a}}$ & $18.0 \pm 0.5^{\mathrm{a}}$ & $18.2 \pm 0.4^{\mathrm{a}}$ \\
\hline Lemak (Lipid) & 2.4 & $4.2 \pm 0.1^{\mathrm{a}}$ & $4.5 \pm 0.7^{a}$ & $7.1 \pm 1.0^{\mathrm{b}}$ \\
\hline Serat kasar (Crude fibre) & 0.3 & $0.3 \pm 0.04^{a}$ & $0.3 \pm 0.2^{\mathrm{a}}$ & $0.3 \pm 0.2^{\mathrm{a}}$ \\
\hline Abu (Ash) & 5.5 & $4.8 \pm 0.1^{\mathrm{a}}$ & $4.8 \pm 0.1^{\mathrm{a}}$ & $4.7 \pm 1.0^{\mathrm{a}}$ \\
\hline BETN (NFE) & 1.3 & $1.6 \pm 0.7^{a}$ & $1.3 \pm 0.7^{a}$ & $0.9 \pm 1.0^{a}$ \\
\hline Air (Water) & 72.2 & $71.9 \pm 0.8^{a}$ & $71.2 \pm 1.6^{\mathrm{a}}$ & $68.9 \pm 0.4^{\mathrm{ab}}$ \\
\hline
\end{tabular}

Keterangan (Remark):

Nilai dalam baris yang sama diikuti oleh superscript yang sama menunjukkan tidak berbeda nyata $(P>0,05)$ (Means in the same row followed by the same superscript are not significantly different $(P>0.05)$ ) 
Tabel 5. Nilai kisaran kualitas air media selama pemeliharaan ikan bandeng di tambak Table5. Range of water quality variables during rearing period of milk fish grow-out in ponds

\begin{tabular}{|c|c|c|c|}
\hline \multirow{2}{*}{$\begin{array}{l}\text { Peubah } \\
\text { Variables }\end{array}$} & \multicolumn{3}{|c|}{ Pakan uji (Test diets) } \\
\hline & $\begin{array}{l}\text { Bungkil kopra } 65 \\
\text { Copra cake } 65\end{array}$ & $\begin{array}{l}\text { Bungkil kopra } 55 \\
\text { Copra cake } 55\end{array}$ & $\begin{array}{l}\text { Pakan komersil } \\
\text { Commercial feed }\end{array}$ \\
\hline Suhu (Temperature) $\left({ }^{\circ} \mathrm{C}\right)$ & $26.3-33.5$ & 26.4-33.2 & $26.7-33.4$ \\
\hline $\begin{array}{l}\text { Oksigen terlarut } \\
\text { Dissolved oxygen (mg/L) }\end{array}$ & $1.1-5.4$ & $0.9-5.7$ & $1.2-6.3$ \\
\hline $\mathrm{pH}$ & $7.5-8.8$ & $7.5-8.4$ & $7.5-8.6$ \\
\hline Salinitas (Salinity ) (ppt) & $5-42$ & $5-42$ & $5-42$ \\
\hline TAN (mg/ L) & $0.016-0.686$ & 0.027-0.709 & $0.010-0.875$ \\
\hline Nitrit (Nitrite) (mg/ L) & $0.002-0.096$ & $0.003-0.094$ & $0.001-0.071$ \\
\hline Nitrat (Nitrate) (mg/ L) & $0.003-0.797$ & $0.002-0.83$ & $0.024-0.875$ \\
\hline Fosfat (Phosphate) (mg/ L) & $0.030-0.374$ & $0.016-0.263$ & $0.003-0.170$ \\
\hline
\end{tabular}

larut sangat rendah pada waktu- waktu tertentu yaitu pada pagi hari sebelum matahari terbit khususnya setelah memasuki awal bulan ke3 , sehingga sejak saat itu mulai dioperasikan kincir pada malam hari. Demikian juga salinitas air berubah mulai dari 5 ppt pada awal penebaran hingga 42 ppt pada akhir pemeliharaan. Perubahan salinitas tambak ini terjadi secara perlahan- Iahan karena ada peralihan dari musim hujan menjadi musim kemarau.

\section{Produktivitas Primer}

Salah satu indikator kesuburan perairan tambak adalah produktivitas primer. Produktivitas primer merupakan laju pembentukan senyawa- senyawa organik yang kaya energi dari senyawa- senyawa anorganik. Semakin tinggi nilai produktivitas primer, semakin subur tambak tersebut. Dinamika produktivitas primer di tambak bandeng disajikan pada Gambar 1 . Nilai produktivitas primer tambak berfluktuasi dari waktu ke waktu, namun memiliki nilai kisaran yang relatif sama di antara petak perlakuan yaitu berkisar antara $120-190 \mathrm{mg} \mathrm{C} / \mathrm{m}^{3} /$ jam atau $1.440-2.280 \mathrm{mg} \mathrm{C} / / \mathrm{m}^{3} /$ hari, sehingga tergolong perairan yang cukup subur plankton. Menurut Rodhe dalam Tumbelaka (1986), perairan yang memiliki nilai produktivitas primer antara $300-3.000 \mathrm{mg} \mathrm{C} / \mathrm{m}^{3} /$ hari merupakan perairan yang tergolong eutrophic.

Nilai produktivitas primer dalam tambak tersebut berkaitan dengan kelimpahan plankton. Semakin tinggi kelimpahan plankton khususnya fitoplankton, maka nilai produktivitas primer juga tinggi. Pada Gambar 2 terlihat pola dinamika kelimpahan plankton di tambak percobaan. Secara umum jumlah kelimpahan plankton untuk petak ikan yang diberi pakan berbasis bungkil kopra $65 \%$ berkisar antara 8.810- $13.940 \mathrm{sel} / \mathrm{L}$, petak ikan yang diberi pakan berbasis bungkil kopra 55\%antara 7.780$13.790 \mathrm{sel} / \mathrm{L}$, dan petak ikan yang diberi pakan komersil antara 7.520- $14.530 \mathrm{sel} / \mathrm{L}$. Hal ini menunjukkan bahwa rataan kelimpahan plankton cukup tinggi untuk semua petak tambak. Hal ini disebabkan karena adanya suplai pupuk anorganik setiap dua minggu untuk semua perlakuan. Abdel- Tawwab et al. (2005) bahkan mendapatkan kepadatan plankton antara 49.000-111.000 sel/L pada tambak ikan belanak (Mugil cephalus) yang diberi pupuk anorganik+organik dan pakan buatan 3\% hari, serta 30.000- 67.000 sel/ L pada tambak yang hanya diberi pakan buatan $5 \%$ hari. Jenis plankton yang tumbuh di dalam tambak dari golongan fitoplankton didominasi oleh jenis Chlorella sp. dan Oscillatoria sp., sementara dari jenis zooplankton didominasi oleh jenis Copepoda, Acartia sp. dan Brachionus sp. Plankton ini merupakan makanan alami yang cukup penting bagi pertumbuhan ikan bandeng.

\section{Bakteri Heterotrof}

Dinamika populasi bakteri heterotrof dalam air tambak disajikan pada Gambar 3. Pada gambar tersebut terlihat bahwa rata- rata populasi bakteri sekitar $10^{4} \mathrm{CFU} / \mathrm{mL}$ dan relatif sama 


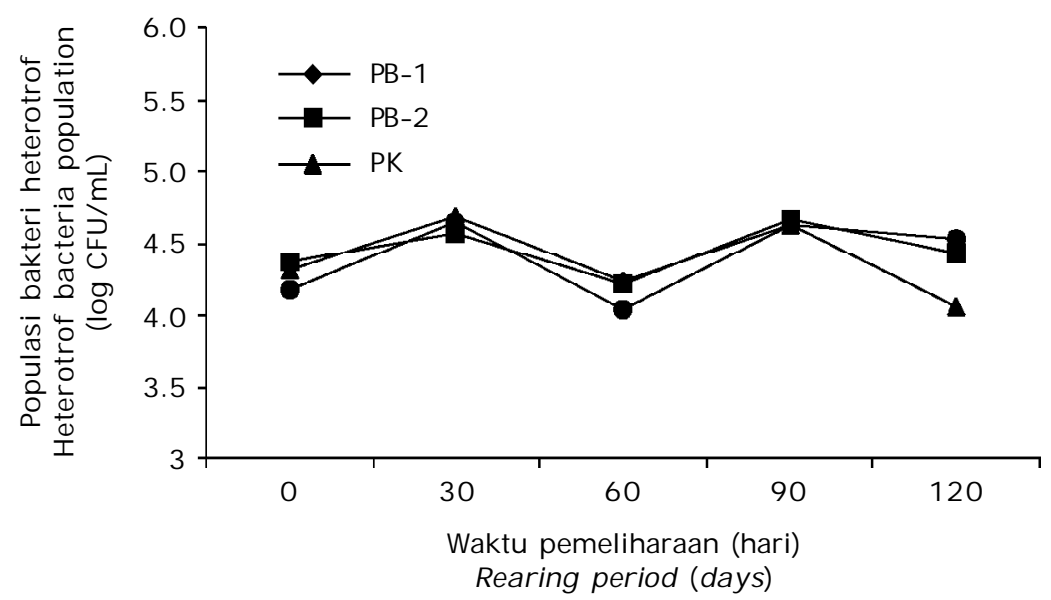

Gambar 3. Pola dinamika po pulasi bakteri heterotrof selama periode pemeliharaan dalam tambak pembesaran ikan bandeng

Figure 3. Dynamic pattern of heterotrof bacteria during rearing period in milkfish pond grow-out

dan terlibat dalam lingkungan dan peran ekologinya relatif sama.

\section{KESIMPULAN}

Pakan bandeng berbasis bungkil kopra (65\% dan 55\%) memiliki koefisien kecernaan bahan kering, protein, lemak dan energi yang lebih rendah dibandingkan pakan komersil. Sementara performansi pertumbuhan ikan seperti laju pertumbuhan harian, konversi pakan, rasio efisiensi protein, retensi protein, dan produksi ikan relatif sama untuk semua pakan uji, kecuali bobot akhir ikan dan retensi lemak yang relatif tinggi pada ikan yang diberi pakan komersil. Pendapatan tertinggi didapatkan berturut- turut pada ikan yang diberi pakan berbasis bungkil kopra $65 \%$ pakan berbasis bungkil kopra 55\% dan pakan komersil. Pakan berbasis bungkil kopra layak digunakan sebagai pakan alternatif dalam pembesaran ikan bandeng tradisional (+) di tambak. Untuk meningkatkan pemanfaatannya, mutu bungkil kopra perlu ditingkatkan kualitasnya.

\section{DAFTAR ACUAN}

Abdel-Tawwab, M., Eid, A.H.M., Abdelghany, A.E., \&El- Marakby, H. 2005. The assessment of water quality and primary production in earthen fishponds stocked with stripped mullet (Mugil cephalus) and subjected to different feeding regime. Turkish Journal of Fisheries and Aquatic Sciences, 5: 1- 10.
AOAC International. 1999. Official Methods of Analysis, $16^{\text {th }}$ edn. Association of Official Analytical Chemists International, Gaithersberg, Maryland, USA, 1,141 pp.

Bagarinao, T.U. 1994. Systematics, distribution, genetics and life history of milkfish, Chanos chanos. Environmental Biology of Fishes, 39: 23- 41 .

De Silva, S.S. \& Perera, M.K. 1984. Digestibility in Sarotherodon niloticus fry: effect of dietary protein level and salinity with further observations on variability in daily digestibility. Aquaculture, 38: 293- 306.

Furuichi, M. 1988. Carbohydrate. Dalam Watanabe T, Editor. Fish Nutrition and Mariculture. Tokyo: Departement of Aquatic Biosciences, University of Fisheries, hIm. 4455.

Hardy, R.W. 1989. Diet preparation. In Halver, J.E. (ed.). Fish Nutrition. Second Edition. Academic Press, Inc. San Diego, p. 476- 549.

Harris, E. 2006. Akuakultur berbasis "Trophic Level": Revitalisasi untuk ketahanan pangan, daya saing ekspor dan kelestarian lingkungan. Orasi IImiah Guru Besar tetap Ilmu Akuakultur, Fakultas Perikanan dan IImu Kelautan, Institut Pertanian Bogor, $65 \mathrm{hlm}$.

Hertrampf, J.W. \& Piedad- Pascual, P. 2000. Handbook on ingredient for aquaculture feeds. Kluwer Academic Publishers, 573 pp.

Huisman, E.A. 1987. Principles of fish production. Department of Fish Culture and Fish- 
eries, Wageningen Agricultural University, Wageningen, Netherlands. 170 pp.

Masagounder, K., Firman, J.D., Hayward, R.S., Sun, S., \& Brown, P.B. 2009. Apparent digestibility of common feedstuffs for bluegill, Lepomis macrochirus and largemouth, Micropterus salmoides using individual test ingredients. Aquaculture Nutrition, 15: 2937.

Millamena, O.M. 2002. The essential nutrients. Dalam: Millamena, O.M, Coloso, R.M., Pascual, F.P., editors. Nutritional in Tropical Aqua-culture. Iloilo, Philippines, SEAFDEC, p. 7- 75

Mohapatra, S., Chakraborty, T., Prusty, A.K., Das, P., Paniprasad, K., \& Mohanta, K.N. 2012. Use of different microbial probiotics in the diet of rohu, Labeo rohita fingerlings: effect on growth, nutrient digestibility and retention, digestive enzyme activities and intestinal microflora. Aquaculture Nutrition, 18: 1- 11.

Newell, G.E. \& Newell, R.C. 1977. Marine Plankton a Practical Guide $5^{\text {th }}$ Edition. Hutchinson of Londong, 244 pp.

Nyina- Wamwiza, L., Wathele, B., Richir, J., Rollin, X., \& Kestemont, P. 2010. Partial or total replacement of fish meal by local aqricultural by- products in diets of juvenile African catfish (Clarias gariepinus): growth performance, feed efficiency and digestibility. Aquaculture Nutrition, 16: 237- 247.

NRC (National Research Council). 1993. Nutrient requirement of fish. National Academy Press, Washington, D.C., $114 \mathrm{pp}$.

Schulz, C., Knaus, U., Wirth, M., \& Rennert, B. 2005. Effect of varying dietary fatty acid propile on growth performance, fatty acid, body and tissue composition of juvenile pike perch (Sander lucioperca). Aquaculture Nutrition, 11: 403-413.

Steel, R.G.D. \& Torrie, J.H. 1995. Prinsip dan Prosedur Statistika. Alih bahasa: Bambang Sumantri. Gramedia Pusaka Utama, Jakarta, $748 \mathrm{hlm}$.

Sudradjat, A. 2010. Aquaculture of milkfish (Bandeng) in Indonesia: Grow- out culture. In: Liao, C.I \& Leano, E.M (Eds.), Milkfish Aquaculture in Asia. National Taiwan
Ocean University, The Fisheries Society of Taiwan, Asian Fisheries Society and World Aquaculture Society, p. 17-30.

Sumagaysay, N.S. 1991. Effect of fibre in supplemental feeds on milkfish (Chanos chanos Forsskal) production in brackishwater ponds. Asian Fisheries Science, 4: 189- 199.

Sumagaysay, N.S. \& Borlongan, I.G. 1995. Growth and production of milkfish (Chanos chanos) in brackishwater ponds: effect of dietary protein and feeding levels. Aquaculture, 132: 273- 283.

Sundu, B., Kumar, A., \& Dingle, J. 2009. Feeding value fo copra meal for broiler. World's Poultry Science Journal, 65: 481- 492.

Takeuchi, T. 1988. Laboratory work-chemical evaluation of dietary nutrients. In: Watanabe, T. (ed.) Fish Nutrition and Mariculture. JICA Kanagawa International Fisheries Training Centre, Tokyo, p. 179- 233.

Tambaru, R. \& Samawi, M.F. 2008. Penentuan selang waktu inkubasi yang terbaik dalam pengukuran produktivitas primer di perairan kepulauan Spermonde. Torani, 8(3): 227238.

Tumbelaka, R. 1986. Produktivitas primer kolamkolam percobaan yang ditebari ikan nila (Oreochromis niloticus Trewavas) dan dipupuk dengan TSP-Urea serta pupuk kandang di stasiun percobaan IPB Darmaga Bogor. Karya IImiah. Jurusan Manajemen Sumberdaya Perairan, Fakultas Perikanan, Institut Pertanian Bogor, $92 \mathrm{hlm}$.

Watanabe, T. 1988. Fish Nutrition and Mariculture. JICA Textbook The General Aquaculture Course. Department of Aquatic Biosciences, Tokyo University of Fisheries. Tokyo, 233 pp.

Yamaji, I. 1979. Illustration of The Marine Plankton of Japan. Hoikusha Publishing Co. Ltd. Osaka Jepang, 350 pp.

Yap, W.T. \&Villaluz, A.C. 2010. Milkfish production systems in brackishwater ponds in the Philippines. In: Liao, C.I \& Leano, E.M (Eds.), Milkfish Aquaculture in Asia. National Taiwan Ocean University, The Fisheries Society of Taiwan, Asian Fisheries Society and World Aquaculture Society, p. 71- 87. 